\title{
Embryonic genotype and inbreeding affect preimplantation development in cattle
}

\author{
G Lazzari ${ }^{1}$, S Colleoni ${ }^{1}$, R Duchi $^{1}$, A Galli $^{2}$, F D Houghton ${ }^{3}$ and C Galli ${ }^{1,4}$ \\ ${ }^{1}$ Avantea, Laboratorio di Tecnologie della Riproduzione, Via Porcellasco 7/f, 26100 Cremona, Italy, ${ }^{2}$ Istituto \\ Sperimentale Italiano Lazzaro Spallanzani, Località La Quercia, 26027 Rivolta d'Adda, Cremona, Italy, ${ }^{3}$ Centre for \\ Human Development, Stem Cells and Regeneration, Human Genetics Division, School of Medicine, University of \\ Southampton, Southampton General Hospital, Tremona Road, Southampton, SO16 6YD, UK and ${ }^{4}$ Dipartimento \\ Clinico Veterinario, Università di Bologna, Via Tolara di Sopra, 50, 40064 Ozzano Emilia, Italy
}

Correspondence should be addressed to G Lazzari; Email: giovannalazzari@avantea.it

\begin{abstract}
Infertility in cattle herds is a growing problem with multifactorial causes. Embryonic genotype and level of inbreeding are among the many factors that can play a role on reproductive efficiency. To investigate this issue, we produced purebred and crossbred bovine embryos by in vitro techniques from Holstein oocytes and Holstein or Brown Swiss semen and analyzed several cellular and molecular features. In the first experiment, purebred and crossbred embryos, obtained from abattoir oocytes, were analyzed for cleavage, development to morula/blastocyst stages, amino acid metabolism and gene expression of developmentally important genes. The results indicated significant differences in the percentage of compacted morulae, in the expression of three genes at the blastocyst stage (MNSOD, GP130 and FGF4) and in the utilization of serine, asparagine, methionine and tryptophan in day 6 embryos. In the second experiment, bovine oocytes were collected by ovum pick up from ten Holstein donors and fertilized with the semen of the respective Holstein sires or with Brown Swiss semen. The derived embryos were grown in vitro up to day 7 , and were then transferred to synchronized recipients and recovered on day 12. We found that purebred/inbred embryos had lower blastocyst rate on days 7-8, were smaller on day 12 and had lower expression of the trophoblast gene PLAC8. Overall, these results indicate reduced and delayed development of purebred embryos compared with crossbred embryos. In conclusion, this study provides evidence that embryo genotype and high inbreeding can affect amino acid metabolism, gene expression, preimplantation development and therefore fertility in cattle. Reproduction (2011) 141 625-632
\end{abstract}

\section{Introduction}

Several investigators have shown a clear decline in reproductive efficiency in dairy cattle over the last 50 years. Butler (1998), in particular, has reported that the first service conception rate has decreased from $\sim 65 \%$ in 1951 to $40 \%$ in 1996 for dairy cattle of New York state. Equivalent declines in reproductive efficiency have occurred in other countries and specific studies have been published for Ireland (Roche et al. 2000), UK (Royal et al. 2000), Spain (Lopez-Gatius 2003) and Australia (Macmillan et al. 1996). Several authors have attributed this decline to the selection for increasing milk production (Butler 1998, Olori et al. 2002, Wall et al. 2005) and published large datasets show a clear inverse relationship between milk production and reproduction efficiency in dairy cattle (Dematawewa \& Berger 1998, Hansen 2000). Other changes, besides increased milk production, have occurred in the dairy cattle industry over the last 50 years. For instance, the decline in the number of dairy herds and the concentration of the dairy industry in larger farms has brought about new challenges in reproductive management. Larger herds require more time for heat detection, record keeping, sorting and insemination and also different strategies from visual heat detection, such as timed artificial insemination. Such strategies can offer management advantages although conception rate is lower (Nebel \& Jobst 1998). By contrast, in herds with poor estrus detection and low fertility, this choice can improve the interval to first service and overall pregnancy rate (Schmitt et al. 1996, Pursley et al. 1997), thus achieving a positive effect on reproductive management. Therefore, the size of the herd and its reproductive management can play an important role in reproductive efficiency. Finally, other factors such as season of calving, post partum diseases (Grohn \& Rajala-Schultz 2000) and negative energy balance in high-producing cows are also involved in the genesis of infertility 
although to variable degree according to numerous published reports (Staples et al. 1990, Lucy et al. 1992).

In addition to all these factors, the rising inbreeding in dairy herds has also been included in the multifactorial causes of low reproductive efficiency. The coefficient of inbreeding measures the percentage of genes of an individual that are identical by descent and, over the last 30 years, this coefficient has increased from about 1 to $\sim 5 \%$ in the Holstein breed. Estimates of the effects of inbreeding on reproduction indicate a detrimental effect on reproductive parameters such that every $1 \%$ increase in inbreeding led to 0.17 increase in service/conception, 2 days increase in the period from calving to conception (days open) and 3.3 percentage-unit decrease in conception rate (Hermas et al. 1987). As a strategy to counterbalance the rise in inbreeding in dairy breeds, crossbreeding has been proposed as a possibility to increase productive and reproductive efficiency (McAllister 2002). The economical benefits of crossbreeding have been reported in a large study in the USA, (VanRaden \& Sanders 2003) and interestingly, a recent in vitro study (Boediono et al. 2003) demonstrated that crossbred embryos develop faster and at higher rate than purebred embryos, suggesting that genotype and possibly inbreeding can influence developmental competence.

In light of all these published reports, the aim of this study was to further investigate the effect of inbreeding on reproductive efficiency by focusing on a number of cellular and molecular parameters of preimplantation development in embryos of different genotype and level of inbreeding.

\section{Results}

\section{Embryo development: experiment 1}

A total number of 2274 oocytes were collected and matured in vitro, 1135 were fertilized with six different Holstein bulls and 1139 with six different Brown Swiss bulls. Oocytes collected from each batch of ovaries were divided and assigned to the crossbred or purebred group to reduce the effect of the oocyte quality. We found no difference in cleavage rate at $30 \mathrm{~h}$ (28.78 vs $26.41 \%$ ) and in total cleavage rate (78.79 vs $74.35 \%)$, although we observed a significant difference in favor of crossbred embryos in the compaction rate on day 6 (26.5 vs $30.03 \% ; P=0.01$ ) and a tendency for higher blastocyst development on day 7 (18.93 vs $20.89 \%$ ) and 8 ( 29.18 vs $33.18 \% ; P=0.07, \chi^{2}$ test). Results are summarized in Table 1.

\section{Amino acid analysis}

Overall, purebred and crossbred embryos displayed a similar amino acid profile but there was a significant difference in the utilization of serine $(P=0.0079)$, asparagine $(P=0.012)$, methionine $(P=0.000)$ and tryptophan ( $P=0.034$ ) between the two groups (Fig. 1$)$. Purebred embryos contained an average of 105.87 \pm 3.12 cells $(n=45)$, which was not significantly different from $108.56 \pm 3.06$ cells $(n=44)$ obtained for crossbred embryos. There was also no difference in total amino acid depletion, appearance or turnover between the two groups (Fig. 2).

\section{Embryo development: experiment 2}

A total of 39 and 40 ovum pick ups (OPUs) were performed on ten Holstein heifers to generate inbred and crossbred embryos respectively. Six hundred and eighty oocytes were fertilized with the Holstein sire of each donor heifer and 688 with four different Brown Swiss bulls chosen from those used in experiment 1 . Results indicate a significantly higher cleavage rate $(74.3$ vs $63.4 \%$, see Table 2 ) for crossbred embryos compared with inbred embryos. In addition, we found that the rate of morula compaction, calculated on the total number of oocytes (22.7 vs $25.4 \%$, see Table 2$)$, the blastocyst rate on day 7 , calculated both on the oocytes and on the cleaved embryos (11.6 and 18.3 vs 18.5 and $24.8 \%$ ), and the blastocyst rate on day 8 , calculated on the oocytes (16.2 vs $22.5 \%)$, were significantly higher for crossbred embryos (Table 2).

The higher developmental rate observed on day 7 was further investigated by transferring the embryos in synchronized recipients and recovering them on day 12 (Fig. 3). A total of 43 inbred embryos and 70 crossbred embryos were transferred on day 7 in eight recipient heifers in total, four recipients for each group. Overall, 29 embryos (67.4\%) and 48 embryos (68.6\%) respectively were recovered on day 12 (Table 3 ). Although the recovery rate was similar in the two groups, we found a significantly higher rate of ovoid embryos (56.3 vs $20.6 \%$ ) in the crossbred group, while in

Table 1 Experiment 1: effect of genotype on embryo development.

\begin{tabular}{|c|c|c|c|c|c|}
\hline $\begin{array}{l}\text { Type of } \\
\text { embryo }\end{array}$ & $\begin{array}{c}\text { Number of } \\
\text { oocytes }\end{array}$ & $\begin{array}{l}\text { Number of } \\
\text { cleaved }(\%)\end{array}$ & $\begin{array}{c}\text { Number of compacted } \\
\text { morulae, day }+\mathbf{6} \\
(\% \text { of cleaved })\end{array}$ & $\begin{array}{c}\text { Number of } \\
\text { blastocysts, day }+7 \\
(\% \text { of cleaved })\end{array}$ & $\begin{array}{c}\text { Number of } \\
\text { blastocysts, day }+\mathbf{8} \\
(\% \text { of cleaved })\end{array}$ \\
\hline Purebred & 1135 & $898(78.79)$ & $238(26.5)^{\mathrm{a}}$ & $170(18.93)$ & $262(29.18)$ \\
\hline Crossbred & 1139 & $847(74.35)$ & $257(30.03)^{\mathrm{b}}$ & $177(20.89)$ & $281(33.18)$ \\
\hline
\end{tabular}

$\chi^{2}$ test. Values within columns with different letters are statistically different $(P<0.05)$. 


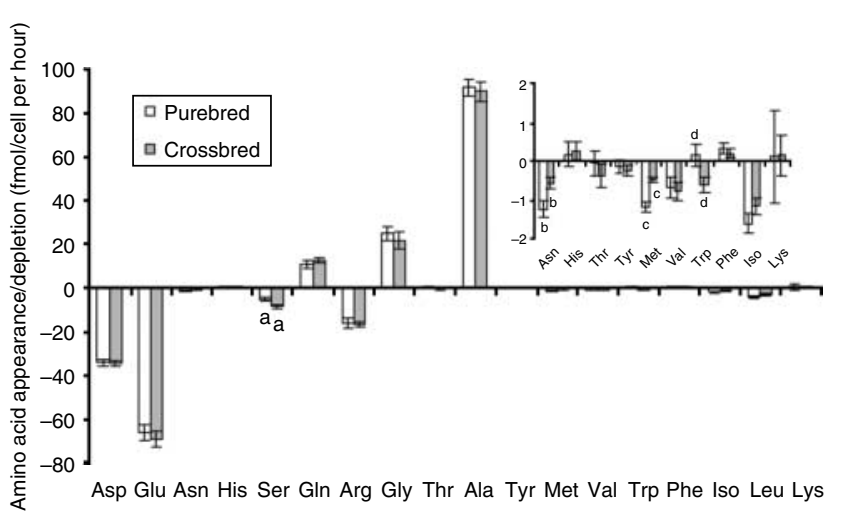

Figure 1 Amino acid depletion/appearance by purebred and crossbred bovine embryos. Inset is an enlargement of those amino acids which have a value between 2 and $-2 \mathrm{fmol} / \mathrm{cell}$ per hour. Bars with the same superscript are significantly different. $a, P=0.0079 ; b, P=0.012$; c, $P=0.000 ; \mathrm{d}, P=0.034$.

the inbred group, most of the embryos were spherical $(79.4$ vs $43.7 \%)$, indicating that also in the second week of development crossbred embryos developed faster and at higher rate. This observation was confirmed also by the difference in the average size of the recovered embryos: crossbred embryos mean size was 0.48 $\pm 0.12 \times 0.40 \pm 0.10 \mathrm{~mm}$ (length $\times$ width) compared with $0.35 \pm 0.18 \times 0.28 \pm 0.09 \mathrm{~mm}$ (length $\times$ width) of inbred embryos.

\section{Gene expression analysis: experiment 1}

Statistical analysis using a Student's $t$-test indicated that, in day 7 blastocysts, the relative expression of three genes was significantly higher in the crossbred group: $M N S O D$, a mitochondrial Mn-superoxide dismutase, GP130, a glycoprotein subunit of the LIF receptor and fibroblast growth factor 4 (FGF4; Fig. 4A). Also PED, the preimplantation embryo development gene, and GJA1 (also known as CX43), a connexin implicated in cellular communication, were more expressed in the crossbred group but without reaching a statistical difference. By contrast, transcripts of stress- and apoptosis-related genes, G6PDH and BAX, a glucose6-phosphate dehydrogenase and the apoptosis regulator box-a had a tendency for higher expression in the purebred group. SLC2A5, a glucose transporter (also know as GLUT5), insulin-like growth factor 1 receptor (IGF1R) and interferon tau (IFNT) showed a similar expression in both groups.

\section{Gene expression analysis: experiment 2}

In day 12 embryos, we found that the genes responsible for embryo elongation, trophoblast development and fetus-maternal interaction, IFNT, CDX2 and PTGS2 (also known as COX2), had a tendency for increased expression in crossbred groups, but only PLAC8 displayed statistical significance using a Student's $t$-test (Fig. 4B). On the contrary, genes involved in programmed cell death such as MSX1 and $B A X$ were slightly more expressed in inbred embryos as previously observed in day 7 blastocyst. Expression of HSP7O was linked more to the season in which the flushing was performed than to the class of embryos: in both groups, inbred and crossbred, the expression of HSP7O was twice as high and statistically different in the summer season from that in the spring (data not shown).

\section{Discussion}

In this study, we have investigated the effect of genotype on embryo development, metabolic activity and gene expression. First of all, we monitored embryo development by examining morphological parameters. In experiment 1, we observed that crossbred embryos derived from oocytes of slaughtered donors had a tendency to cleave faster than purebred embryos. Interestingly, several studies performed on different species have demonstrated that the time of first cleavage is positively correlated with the developmental competence of the embryos (van Soom et al. 1997, Fenwick et al. 2002) and it was demonstrated that bovine fastcleaving embryos have a different gene expression that reflects their higher quality compared with late-cleaving embryos (Gutierrez-Adan et al. 2004). Another determining step for embryo development before blastocyst formation is the compaction of the morula on day 6 . In experiment 1, we found that crossbred embryos have a significantly higher rate of compaction compared with purebred and inbred embryos, strongly indicating a greater competence/quality of this group. This finding was confirmed in experiment 2 in which we observed higher blastocyst development of crossbred embryos. Remarkably, this trend was confirmed by the data on embryo development at day 12 , where we demonstrated that crossbred embryos undergo elongation at a higher rate compared with inbred embryos. Elongation is a crucial step for bovine embryo development since most embryonic losses occur between blastulation and elongation (Diskin \& Sreenan 1980) and embryos more advanced on day 12 establish pregnancies at significantly higher rate than smaller embryos (Lazzari et al. 2002). Therefore, our observations, starting from the

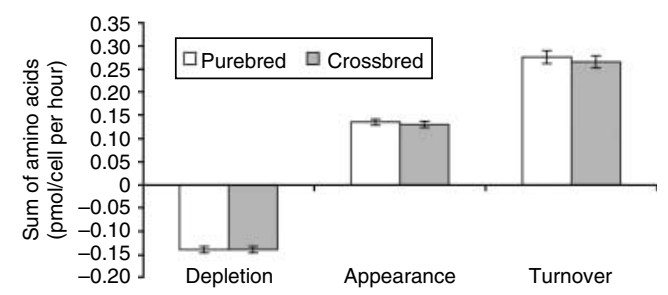

Figure 2 Total amino acid depletion, appearance and turnover for purebred and crossbred bovine embryos. 
Table 2 Experiment 2: effect of genotype on embryo development.

\begin{tabular}{|c|c|c|c|c|c|c|}
\hline $\begin{array}{l}\text { Type of } \\
\text { embryo }\end{array}$ & $\begin{array}{l}\text { Number of } \\
\text { OPUs }\end{array}$ & $\begin{array}{l}\text { Number of } \\
\text { oocytes }\end{array}$ & $\begin{array}{c}\text { Number of } \\
\text { cleaved } \\
(\%)\end{array}$ & $\begin{array}{c}\text { Number of } \\
\text { compacted } \\
\text { morulae, day }+\mathbf{6} \\
(\% \text { of oocytes }) \\
(\% \text { of cleaved })\end{array}$ & $\begin{array}{c}\text { Number of } \\
\text { blastocysts, day }+7 \\
\text { (\% of oocytes) } \\
\text { (\% of cleaved) }\end{array}$ & $\begin{array}{c}\text { Number of } \\
\text { blastocysts, day }+\mathbf{8} \\
\text { (\% of oocytes) } \\
\text { (\% of cleaved) }\end{array}$ \\
\hline Inbred & 39 & 680 & $\begin{array}{c}431 \\
(63.4)^{\mathrm{a}}\end{array}$ & $\begin{array}{c}98 \\
(14.4)^{\mathrm{a}} \\
(22.7)^{\mathrm{A}}\end{array}$ & $\begin{array}{c}79 \\
(11.6)^{\mathrm{a}} \\
(18.3)^{\mathrm{A}}\end{array}$ & $\begin{array}{c}110 \\
(16.2)^{\mathrm{a}} \\
(25.5)^{\mathrm{A}}\end{array}$ \\
\hline Crossbred & 40 & 688 & $\begin{array}{c}511 \\
(74.3)^{\mathrm{b}}\end{array}$ & $\begin{array}{c}138 \\
(20.1)^{\mathrm{b}} \\
(25.4)^{\mathrm{A}}\end{array}$ & $\begin{array}{c}127 \\
(18.5)^{\mathrm{b}} \\
(24.8)^{\mathrm{B}}\end{array}$ & $\begin{array}{c}155 \\
(22.5)^{\mathrm{b}} \\
(30.3)^{\mathrm{A}}\end{array}$ \\
\hline
\end{tabular}

$\chi^{2}$ test. Values within columns with different letters are statistically different $(P<0.05)$.

early cleavage stage to elongation, indicate a higher developmental capacity and most likely a higher ability to establish pregnancies for crossbred embryos. This detrimental effect of inbreeding on embryo development reminds, to some extent, the fact that in the mouse, most outbred stocks and some inbred strains display a compromised in vitro embryo development that is normally not observed in hybrids (Scott \& Whittingham 1996). All together, these findings further confirm that embryo genotype can play a significant role during early embryo development and also highlight the importance of the preservation of rare and endangered breeds to maintain the species gene pool as wide as possible.

The level of amino acids utilized by purebred and crossbred embryos were found to be similar to that previously observed in bovine blastocysts (Gopichandran \& Leese 2003). Although the overall depletion, appearance and turnover of amino acids were not significantly different between purebred and crossbred embryos, there was a significant difference in the utilization of serine, asparagine, methionine and tryptophan. This suggests that purebred embryos have a different amino acid requirement from crossbred embryos. To the best of our knowledge, this is the first report of genotype affecting the amino acid utilization of bovine embryos.

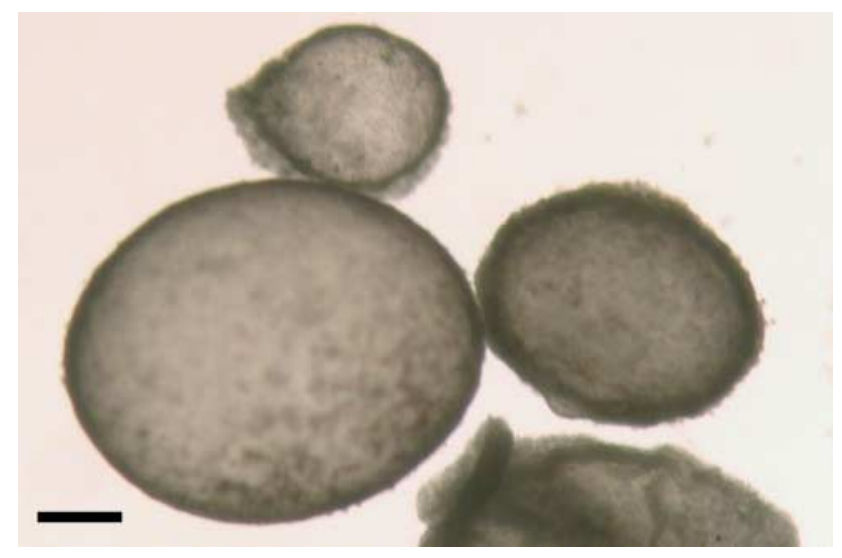

Figure 3 Ovoid and spherical day 12 embryos transplanted at day 7 in synchronized recipients and recovered after 5 days. Scale bar corresponds to $200 \mu \mathrm{M}$.
Regarding gene expression, we examined a panel of genes indicative of embryo quality, developmental competence, metabolism and stress reactivity. Among them, MNSOD is a mitochondrial Mn-superoxide dismutase that indicates mitochondrial activity and also has a role in detoxification of reactive oxygen species, cellular differentiation and embryo compaction. As recently demonstrated (Lonergan et al. 2003), the level of MNSOD expression is higher in in vivo-produced embryos in respect to those produced in vitro. Therefore, the higher level of expression found in the crossbred group suggests greater mitochondrial activity and improved quality compared with the purebred group. Two other genes significantly up-regulated in the crossbred group are GP130 and FGF4. In bovine embryos, both genes start to be expressed at the time of morula compaction and the expression is maintained during blastulation. In the mouse, Fgf4 is also expressed at the morula to blastocyst stage and is required for normal development since Fgf4 null embryos undergo implantation but do not develop substantially thereafter (Feldman et al. 1995). Published bovine data indicate that embryos with low developmental potential, such as nuclear transfer embryos, have lower or absent FGF4 expression, therefore suggesting an important role for this gene. (Daniels et al. 2000). GP130 is a LIF and interleukin 6 receptor subunit, and even if it is not clear whether the LIF-LIF receptor system has, in ruminant embryos, the same role in implantation known in the mouse, it was demonstrated that addition of LIF to the culture of ovine blastocysts significantly improves pregnancy rate after transfer in recipients ewes (Fry et al. 1992). In summary, a higher expression of FGF4 and GP130 can indicate, as mentioned above for MNSOD, a higher developmental and implantation competence of the crossbred group. Another examined gene was $P E D$. Interestingly, in vivo-cultured embryos and early-cleaving embryos show high expression of PED (Fair et al. 2004), and these observations applied to our results suggest that crossbred group have both higher quality and greater developmental potential. GJA1 also displayed an increased expression in the crossbred group, and like $P E D$, a higher level of expression has 
Table 3 Development and size of day 12 inbred and crossbred embryos after in vivo culture.

\begin{tabular}{|c|c|c|c|c|c|c|c|}
\hline & $\begin{array}{c}\text { Number } \\
\text { of embryos } \\
\text { transferred on } \\
\text { day }+7\end{array}$ & $\begin{array}{c}\text { Number } \\
\text { of embryos } \\
\text { recovered on } \\
\text { day }+12\end{array}$ & $\begin{array}{c}\text { Recovery rate } \\
(\%)\end{array}$ & $\begin{array}{c}\text { Number of ovoid } \\
\text { embryos }\end{array}$ & $\begin{array}{l}\text { Percentage of } \\
\text { recovered }\end{array}$ & $\begin{array}{c}\text { Number of } \\
\text { spheric embryos }\end{array}$ & $\begin{array}{l}\text { Percentage } \\
\text { of recovered }\end{array}$ \\
\hline Inbred & 43 & 29 & 67.4 & 7 & $20.6^{\mathrm{a}}$ & 27 & $79.4^{\mathrm{a}}$ \\
\hline Crossbred & 70 & 48 & 68.6 & 27 & $56.3^{b}$ & 21 & $43.7^{\mathrm{b}}$ \\
\hline
\end{tabular}

$\chi^{2}$ test. Values within columns with different letters are statistically different $(P<0.05)$.

been found in faster-developing embryos (GutierrezAdan et al. 2004), indicating that this gene is associated with embryo quality. Remarkably, GJA1, which is involved in gap junctional intracellular communication and compaction, was higher in crossbred embryos which displayed an increased rate of compaction compared with purebred embryos. The genes related to stress and apoptosis tended to display increased expression in the purebred embryos, although the difference was not significant. $B A X$ is a proapoptotic gene previously suggested to be a marker of blastocyst quality with the level of expression being lower in good-quality embryos. $G 6 P D H$ was defined as sentinel for oxidative stress (Lonergan et al. 2003), and in this study, the expression is higher in the inbred group. G6PDH is an enzyme indispensable for maintaining the cellular redox state and the high level suggests a stressful condition for the embryo.

The same higher developmental competence in terms of gene expression was also observed comparing ovoid day 12 crossbred and inbred embryos. The expression of IFNT, a trophoblastic-specific gene (Degrelle et al. 2005) strictly involved in embryo-endometrial interaction and pregnancy signalling (Spencer et al. 2008) and also other elongation- and implantationrelated genes, such as PLAC8, CDX2 and PTGS2, displayed increased expression in crossbred ovoid embryos. Recently, it was demonstrated that these three latter genes are more expressed in biopsies of blastocysts, resulting in the delivery of a calf, compared with those resulting in resorption (El-Sayed et al. 2006). In the same work, it was observed that genes linked to programmed cell death such as MSX1 were up-regulated in embryos, resulting in no pregnancy. Our data indicated that MSX1 was more expressed in the inbred group and, as previously observed in day 7 embryos, $B A X$ expression was also slightly higher. Interestingly, we found that HSP7O expression was significantly higher in both groups in the summer season compared with the spring, indicating a high level of stress induced by environmental conditions. This casual observation demonstrates that the temperature to which the embryos are exposed plays an important role in the expression of stress-related genes and should be always taken into account in an experimental design.

A final particular aspect to be considered about experiment 2 is that the data refer to embryos with extreme inbreeding levels, inbred-purebred, that are not commonly found in bovine herds. Therefore, a more accurate evaluation of the embryonic effects of different levels of inbreeding, within the Holstein breed for example, is needed to identify the threshold level that can negatively affect the developmental characteristics of preimplantation bovine embryos. These data, when available, could be integrated with recent findings on candidate genes and pathways affecting fertilization rate and early embryo development (Khatib et al. 2009, Wang et al. 2009). Ultimately, all this information would be of practical use in the design of selection breeding programmes.

In conclusion, this study demonstrates, using a panel of cellular, metabolic and molecular parameters, that embryo genotype and high inbreeding affect embryonic development in the first 2 weeks after fertilization, a period that represents the crucial developmental window bringing to the establishment of pregnancy in cattle.

Finally, this study was conducted on purebred Holstein Friesian and crossbred Holstein Friesian-Brown Swiss embryos; therefore, more research is needed to further investigate the embryonic consequences of inbreeding and crossbreeding in other cattle breeds.
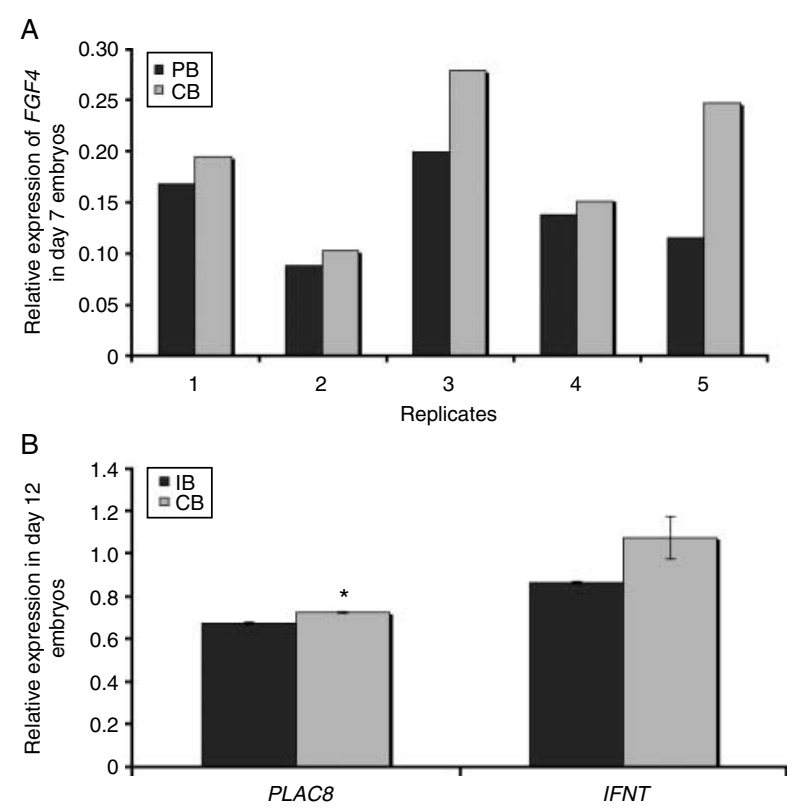

Figure 4 (A) Relative expression of FGF4 in purebred and crossbred blastocyts in five different experimental groups. (B) Relative expression of PLAC8 and IFNT in inbred and crossbred day 12 embryos. 


\section{Materials and Methods}

In this study, we compared groups of in vitro-produced embryos of two different origins: purebred embryos produced by fertilizing Holstein oocytes with Holstein semen and crossbred embryos obtained by fertilizing Holstein oocytes with Brown Swiss semen. The study was carried out in two separate experiments using either oocytes collected at the abattoir from slaughtered donors (experiment 1) or oocytes recovered by OPU from live donors (experiment 2). Different Holstein and Brown Swiss bulls were used for each replicate. For experiment 2, the bull sire of each heifer was chosen for IVF in order to produce highly inbred embryos. All the derived embryos were observed during in vitro development, evaluating the time of first cleavage, compaction at day 6 and blastocyst rate at days 7 and 8 . In addition, part of the blastocysts derived from experiment 1 were analyzed for the pattern of expression of transcripts implicated in pre- and postimplantation periods, embryo metabolism, apoptosis and oxidative stress and the others were used for the evaluation of amino acid turnover. Embryo viability during the second week of development was investigated by transferring blastocysts derived from experiment 2 , inbred and crossbred, in synchronous recipients on day 7 of the cycle. These embryos were nonsurgically recovered 5 days later, on day 12 , to evaluate their size, gene expression pattern and stage of development.

\section{Experiment 1}

Oocyte collection, maturation, fertilization and embryo culture. All chemicals were purchased from Sigma-Aldrich, unless otherwise indicated.

Ovaries of Holstein cows were collected immediately after slaughter and transported to the laboratory in Dulbecco's PBS with antibiotics. Oocytes recovered by aspiration were selected for uniform, non-expanded and non-atretic cumulus morphology, and were matured for $20-24 \mathrm{~h}$ at $38.5{ }^{\circ} \mathrm{C}$ in $5 \%$ $\mathrm{CO}_{2}$ and $5 \% \mathrm{O}_{2}$ in TCM199 supplemented with $10 \%$ FCS, gonadotropins (FSH and LH, 0.05 IU each; Pergovet, Serono), insulin, transferrin, sodium selenite (ITS), Long-IGF1 (100 ng/ml) and Long-EGF (50 ng/ml).

After maturation, oocytes were assigned to one of the two following groups: 1) purebred, 2) crossbred. Group 1 oocytes were fertilized with semen of Holstein bulls and group 2 oocytes were fertilized with semen of Brown Swiss bulls for a total of six replicates. After thawing, the semen was separated on a Percoll gradient and resuspended in synthetic oviduct fluid (SOF) medium (Tervit et al. 1972), HEPES buffered and supplemented with fatty acid-free BSA (6 mg/ml), modified Eagle medium (MEM) amino acids, $1 \mu \mathrm{g} / \mathrm{ml}$ heparin, $20 \mu \mathrm{M}$ penicillamine, $1 \mu \mathrm{M}$ epinephrine and $10 \mu \mathrm{M}$ hypotaurine. Matured oocytes were coincubated with the semen for $18-20 \mathrm{~h}$ at $38.5{ }^{\circ} \mathrm{C}$ in $5 \% \mathrm{CO}_{2}$ and $5 \% \mathrm{O}_{2}$.

Zygotes were cultured in groups of 50-80 embryos in $400 \mu \mathrm{l}$ of $\mathrm{m}$-SOF (modified SOF) medium supplemented with MEM amino acids and BSA $(4 \mathrm{mg} / \mathrm{ml})$ until day 8 , performing $50 \%$ changes of medium at day 4 and 6 at the same atmosphere as above. Each group was evaluated $30 \mathrm{~h}$ post fertilization to assess the first embryonic cleavage. Cleavage rate, compaction at day 6 and blastocyst rate at days 7 and 8 were recorded.

\section{Amino acid analysis}

Forty-five purebred and 43 crossbred, day 6, compacted morula were washed twice in SOF medium containing a complete mixture of amino acids (Tay et al. 1997) and cultured individually in $6 \mu \mathrm{l}$ drops of this medium for $16 \mathrm{~h}$. Embryo-free control drops of medium were also included in each dish to allow for any non-specific amino acid degradation. After incubation, the embryos were removed from the drops, fixed for $24 \mathrm{~h}$ in acetic acid: ethanol (1:3) mixture and stained with Lacmoid to count the number of cells. The spent medium was stored at $-80{ }^{\circ} \mathrm{C}$ prior to amino acid analysis. The concentration of amino acids was determined by reverse-phase HPLC using a modification of a previously described method (Stokes et al. 2007). The spent medium $(2 \mu \mathrm{l})$ was diluted with $23 \mu \mathrm{l}$ HPLC-grade water and amino acid analysis was performed on an automated Agilent $1100 \mathrm{HPLC}$ fitted with a Gemini $3 \mu \mathrm{m}$ $50 \times 4.6 \mathrm{~mm}$ C18 column (Phenomenex, Macclesfield, UK) and an Agilent fluorescence detector. Equal volumes of diluted samples and $o$-phthaldialdehyde were mixed and $5 \mu$ of the solution was loaded onto the column. An elution gradient was established at a flow rate of $2.5 \mathrm{ml} / \mathrm{min}$. Solvent A consisted of $80 \% 83 \mathrm{mM}$ sodium acetate $(\mathrm{pH} 5.9), 18.5 \%$ methanol and $1.5 \%$ tetrahydrofuran. Solvent B consisted of $80 \%$ methanol and $20 \%$ sodium acetate $(\mathrm{pH} 5.9)$. Using this method, it was not possible to detect cysteine and proline.

\section{Experiment 2}

Oocyte recovery by OPU, maturation, fertilization and embryo culture.

Ten Holstein heifers were used as oocyte donors by OPU. Oocyte collection was performed by transvaginal ultrasoundguided follicular aspiration (Galli et al. 2001). Briefly, all ovarian follicles ranging from 3 to $15 \mathrm{~mm}$ size were aspirated using a $17 \mathrm{G}, 55 \mathrm{~cm}$ long, single-lumen cannula with a $19 \mathrm{G}$ long spinal needle mounted at the tip connected to an aspiration pump. Collected oocytes were in vitro matured as previously described in experiment 1. Each oocyte batch was fertilized either with the semen of the heifer's sire (inbred group) or with Brown Swiss semen (crossbred group), giving rise to purebred-inbred embryos or crossbred embryos. Development was assessed observing cleavage rate, compaction at day 6 and blastocysts formation at days 7 and 8 as in experiment 1 .

To evaluate embryo development in the second week post fertilization, pools of day 7 in vitro-grown inbred or crossbred blastocysts were nonsurgically transferred in synchronized recipients on day 7 of the cycle (Bowen et al. 1978). On day 12 , the embryos were collected with a Dissi catheter (Minitub, Tiefenbach, Germany) by flushing the uterine horns using Dulbecco PBS supplemented with 1\% FCS. The fluid was recovered in glass bottles and the embryos were allowed to settle. The supernatant was aspirated, the embryos were collected from the bottom and placed in HEPES-buffered SOF. Length and width of all recovered embryos were measured under a stereomicroscope, with the aid of a calibrated ruler (Lazzari et al. 2002). After multiple washings in PBS supplemented with $1 \mathrm{mg} / \mathrm{ml}$ of polyvinyl alcohol, embryos were collected in RNAase DNAse free tubes and snap-frozen for PCR analysis. 
Table 4 Primers for RT-PCR.

\begin{tabular}{|c|c|c|}
\hline Genes & Primer & $\begin{array}{l}\text { Fragment } \\
\text { size }(b p)\end{array}$ \\
\hline MNSOD & $\begin{array}{l}\text { 5'-CCCATGAAGCCTTTCTAATCCTG } \\
\text { 3'-TTCAGAGGCGCTACTATTTCCTTC }\end{array}$ & 307 \\
\hline PED & $\begin{array}{l}\text { 5'-GCACTACGGCTACGAAGGCAGAG } \\
\text { 3'-TCTCCACAAGCTCCATGTCCTG }\end{array}$ & 350 \\
\hline SLC2A5 & $\begin{array}{l}\text { 5'-CATCTCCATCATCGTCCTCA } \\
\text { 3'-GTAGATGGTGGTGAGGAGAC }\end{array}$ & 531 \\
\hline GP130 & $\begin{array}{l}\text { 5'-TCGTGCCTGTTTGCTTAGCATTCCTATTGA } \\
\text { 3'-CTGCTAGAAATGCTTGGCCTAGAAGATGAC }\end{array}$ & 367 \\
\hline FGF4 & $\begin{array}{l}\text { 5'-TTCTTCGTGGCCATGAGCAG } \\
\text { 3'-AGGAAGTGGGTGACCTTCAT }\end{array}$ & 208 \\
\hline$I G F 1 R$ & $\begin{array}{l}\text { 5'-TTGAACTGATGCGCCATGTGCTGG } \\
\text { 3'-TGCTTCTTGCGGCCCCCGTTCAT }\end{array}$ & 210 \\
\hline IFNT & $\begin{array}{l}\text { 5'-GCCCTGGTGCTGGTCAGCTA } \\
\text { 3'-CATCTTAGTCAGCGAGAGTC }\end{array}$ & 564 \\
\hline GJA1 & $\begin{array}{l}\text { 5'-TGGAATGCAAGAGAGGTTGAAAGAGG } \\
\text { 3'-AACACTCTCCAGAACACATGATCG }\end{array}$ & 293 \\
\hline$B A X$ & $\begin{array}{l}\text { 5'-TGCAGAGGATGATCGCAGCTGTG } \\
\text { 3'-CCAATGTCCAGCCCATCATGGTC }\end{array}$ & 198 \\
\hline G6PDH & $\begin{array}{l}\text { 5'-CGCTGGGACGGGGTGCCCTTCATC } \\
\text { 3'-CGCCAGGCCTCCCGCAGTTCATCA }\end{array}$ & 347 \\
\hline
\end{tabular}

\section{Gene expression analysis}

Total RNA was extracted from pools of fifteen day 7 blastocysts from each purebred and crossbred group or from day 12 inbred and crossbred embryos (RNeasy mini kit, Qiagen). Day 12 embryos were analyzed in pools of two embryos and each embryo was considered equivalent to a group of fifteen day 7 embryos and cDNA was diluted in the same volume. The RT reaction was performed immediately after extraction (First strand cDNA synthesis kit; Fermentas, St Leon-Rot, Germany) for $10 \mathrm{~min}$ at $25^{\circ} \mathrm{C}$ followed by a retro-transcription step of $1 \mathrm{~h}$ at $38^{\circ} \mathrm{C}$ and a $70^{\circ} \mathrm{C}$ step for $10 \mathrm{~min}$. The PCR was performed in a total volume of $25 \mu \mathrm{l}$ containing $2.5 \mu \mathrm{l}$ of $10 \times$ PCR buffer with $1.5 \mathrm{mM}$ of $\mathrm{MgCl}_{2}$ (supplied with HotStarTaq DNA Polymerase, Qiagen), $250 \mu \mathrm{M}$ of each dNTP, $1 \mu \mathrm{M}$ of each specific primer, $0.625 \mathrm{IU}$ of Hot Start Taq Polymerase (HotStarTaq DNA Polymerase, Qiagen) and a volume of cDNA equivalent at 0.5 or 1 embryo for day 7 , as indicated in Table 4 . The reaction was performed using an MJ Minicycler (Bio-Rad) with the following program: $15 \mathrm{~min}$ at $95^{\circ} \mathrm{C}$ as initial step followed by 30 cycles ( 35 cycles were applied for FGF4 and GJA1) of $30 \mathrm{~s}$ at $95{ }^{\circ} \mathrm{C}, 30 \mathrm{~s}$ at $57{ }^{\circ} \mathrm{C}$ and $45 \mathrm{~s}$ at $72{ }^{\circ} \mathrm{C}$. The final step of the last cycle was prolonged to $5 \mathrm{~min}$ at $72{ }^{\circ} \mathrm{C}$ as final extension. For each sample, two negative controls were prepared, one in which reverse transcriptase was omitted during RT reaction and one in which cDNA was omitted during PCR reaction.

After RT-PCR reaction, the samples were cooled at $4{ }^{\circ} \mathrm{C}$ and electrophoresis was performed on a $2.5 \%$ agarose gel in $1 \times$ TAE buffer containing $0.5 \mu \mathrm{g} / \mathrm{ml}$ of ethidium bromide. Running buffer was the same $1 \times$ TAE buffer supplemented with ethidium bromide. The results of the electrophoresis were captured with a Gel Logic 100 Imaging System (Eastman Kodak Company) and images were analyzed with a Kodak Molecular Imaging Software. The intensity of each band was analyzed by densitometry and the results were normalized using Histone $\mathrm{H} 2 \mathrm{a}$ as a standard gene. Genes analyzed for day 7 blastocysts were selected from the literature with the objective of providing an indication of the effects of embryo genotype and level of inbreeding on embryo quality, developmental competence and response to stress: MNSOD, SLC2A5, IGF1R, IFNT, G6PDH, BAX, GJA1 (Gutierrez-Adan et al. 2004), GP130 (Eckert \& Niemann 1998), FGF4 (Daniels et al. 2000) and PED (Fair et al. 2004). Primers are listed in Table 4. Genes examined in day 12 embryos included trophoblast-specific genes and proapoptotic genes: IFNT and BAX (Gutierrez-Adan et al. 2004), PTGS2, PLAC8, MSX1 (El-Sayed et al. 2006) and CDX2 (Degrelle et al. 2005).

\section{Statistical analysis}

Embryos development data were analyzed with $\chi^{2}$ test, while statistical differences in genes expression were determined with Student's $t$-test.

All amino acid data were analyzed to determine whether they were normally distributed using the Anderson-Darling normality test. Differences between amino acid appearance/ depletion and turnover between purebred and crossbred embryos were determined using Student's $t$-test or Mann Whitney $U$ test.

\section{Declaration of interest}

The authors declare that there is no conflict of interest that could be perceived as prejudicing the impartiality of the research reported.

\section{Funding}

This work was supported by Regione Lombardia (Projects 'Embryofert' and 'Uterofert'), by EU (Framework VII, project 223485, acronym 'Plurisys'), by MIPAF (RiproSel Project), Fondazione Cariplo (Nobel Project) and the UK Medical Research Council (G0701153).

\section{Acknowledgements}

The authors acknowledge the technical support of Gabriella Crotti, Paola Turini and Massimo lazzi.

\section{References}

Boediono A, Suzuki T \& Godke RA 2003 Comparison of hybrid and purebred in vitro-derived cattle embryos during in vitro culture. Animal Reproduction Science 78 1-11. (doi:10.1016/S0378-4320(03)00065-4)

Bowen JM, Elsden RP \& Seidel GE Jr 1978 Non-surgical embryo transfer in the cow. Theriogenology 10 89-95. (doi:10.1016/0093-691X(78) 90083-3)

Butler WR 1998 Review: effect of protein nutrition on ovarian and uterine physiology in dairy cattle. Journal of Dairy Science 81 2533-2539. (doi:10.3168/jds.S0022-0302(98)70146-8)

Daniels R, Hall V \& Trounson AO 2000 Analysis of gene transcription in bovine nuclear transfer embryos reconstructed with granulosa cell nuclei. Biology of Reproduction 63 1034-1040. (doi:10.1095/biolreprod63.4.1034)

Degrelle SA, Campion E, Cabau C, Piumi F, Reinaud P, Richard C, Renard JP \& Hue I 2005 Molecular evidence for a critical period in mural trophoblast development in bovine blastocysts. Developmental Biology 288 448-460. (doi:10.1016/j.ydbio.2005.09.043) 
Dematawewa CM \& Berger PJ 1998 Genetic and phenotypic parameters for 305-day yield, fertility, and survival in Holsteins. Journal of Dairy Science 81 2700-2709. (doi:10.3168/jds.S0022-0302(98)75827-8)

Diskin MG \& Sreenan JM 1980 Fertilization and embryonic mortality rates in beef heifers after artificial insemination. Journal of Reproduction and Fertility 59 463-468. (doi:10.1530/jrf.0.0590463)

Eckert J \& Niemann H 1998 mRNA expression of leukaemia inhibitory factor (LIF) and its receptor subunits glycoprotein 130 and LIF-receptorbeta in bovine embryos derived in vitro or in vivo. Molecular Human Reproduction 4 957-965. (doi:10.1093/molehr/4.10.957)

El-Sayed A, Hoelker M, Rings F, Salilew D, Jennen D, Tholen E, Sirard MA, Schellander K \& Tesfaye D 2006 Large-scale transcriptional analysis of bovine embryo biopsies in relation to pregnancy success after transfer to recipients. Physiological Genomics 28 84-96. (doi:10.1152/physiolgenomics.00111.2006)

Fair T, Gutierrez-Adan A, Murphy M, Rizos D, Martin F, Boland MP \& Lonergan P 2004 Search for the bovine homolog of the murine ped gene and characterization of its messenger RNA expression during bovine preimplantation development. Biology of Reproduction 70 488-494. (doi:10.1095/biolreprod.103.022137)

Feldman B, Poueymirou W, Papaioannou VE, DeChiara TM \& Goldfarb M 1995 Requirement of FGF-4 for postimplantation mouse development. Science 267 246-249. (doi:10.1126/science.7809630)

Fenwick J, Platteau P, Murdoch AP \& Herbert M 2002 Time from insemination to first cleavage predicts developmental competence of human preimplantation embryos in vitro. Human Reproduction 17 407-412. (doi:10.1093/humrep/17.2.407)

Fry RC, Batt PA, Fairclough RJ \& Parr RA 1992 Human leukemia inhibitory factor improves the viability of cultured ovine embryos. Biology of Reproduction 46 470-474. (doi:10.1095/biolreprod46.3.470)

Galli C, Crotti G, Notari C, Turini P, Duchi R \& Lazzari G 2001 Embryo production by ovum pick up from live donors. Theriogenology $\mathbf{5 5}$ 1341-1357. (doi:10.1016/S0093-691X(01)00486-1)

Gopichandran N \& Leese HJ 2003 Metabolic characterization of the bovine blastocyst, inner cell mass, trophectoderm and blastocoel fluid. Reproduction 126 299-308. (doi:10.1530/rep.0.1260299)

Grohn YT \& Rajala-Schultz PJ 2000 Epidemiology of reproductive performance in dairy cows. Animal Reproduction Science 60-61 605-614. (doi:10.1016/S0378-4320(00)00085-3)

Gutierrez-Adan A, Rizos D, Fair T, Moreira PN, Pintado B, de la Fuente J, Boland MP \& Lonergan P 2004 Effect of speed of development on mRNA expression pattern in early bovine embryos cultured in vivo or in vitro. Molecular Reproduction and Development 68 441-448. (doi:10.1002/ mrd.20113)

Hansen LB 2000 Consequences of selection for milk yield from a geneticist's viewpoint. Journal of Dairy Science 83 1145-1150. (doi:10.3168/jds.S0022-0302(00)74980-0)

Hermas SA, Young CW \& Rust JW 1987 Effects of mild inbreeding on productive and reproductive performance of Guernsey cattle. Journal of Dairy Science 70 712-715. (doi:10.3168/jds.S0022-0302(87)80062-0)

Khatib H, Huang W, Wang X, Tran AH, Bindrim AB, Schutzkus V, Monson RL \& Yandell BS 2009 Single gene and gene interaction effects on fertilization and embryonic survival rates in cattle. Journal of Dairy Science 92 2238-2247. (doi:10.3168/jds.2008-1767)

Lazzari G, Wrenzycki C, Herrmann D, Duchi R, Kruip T, Niemann H \& Galli C 2002 Cellular and molecular deviations in bovine in vitroproduced embryos are related to the large offspring syndrome. Biology of Reproduction 67 767-775. (doi:10.1095/biolreprod.102.004481)

Lonergan P, Rizos D, Gutierrez-Adan A, Moreira PM, Pintado B, de la Fuente J \& Boland MP 2003 Temporal divergence in the pattern of messenger RNA expression in bovine embryos cultured from the zygote to blastocyst stage in vitro or in vivo. Biology of Reproduction 69 1424-1431. (doi:10.1095/biolreprod.103.018168)

Lopez-Gatius F 2003 Is fertility declining in dairy cattle? A retrospective study in northeastern Spain. Theriogenology 60 89-99. (doi:10.1016/ S0093-691X(02)01359-6)

Lucy MC, Savio JD, Badinga L, De La Sota RL \& Thatcher WW 1992 Factors that affect ovarian follicular dynamics in cattle. Journal of Animal Science 70 3615-3626.

Macmillan KL, Lean IJ \& Westwood CT 1996 The effects of lactation on the fertility of dairy cows. Australian Veterinary Journal 73 141-147. (doi:10. 1111/j.1751-0813.1996.tb10007.x)
McAllister AJ 2002 Is crossbreeding the answer to questions of dairy breed utilization? Journal of Dairy Science 85 2352-2357. (doi:10.3168/jds. S0022-0302(02)74315-4)

Nebel RL \& Jobst SM 1998 Evaluation of systematic breeding programs for lactating dairy cows: a review. Journal of Dairy Science 81 1169-1174. (doi:10.3168/jds.S0022-0302(98)75679-6)

Olori VE, Meuwissen TH \& Veerkamp RF 2002 Calving interval and survival breeding values as measure of cow fertility in a pasture-based production system with seasonal calving. Journal of Dairy Science 85 689-696. (doi:10.3168/jds.S0022-0302(02)74125-8)

Pursley JR, Kosorok MR \& Wiltbank MC 1997 Reproductive management of lactating dairy cows using synchronization of ovulation. Journal of Dairy Science 80 301-306. (doi:10.3168/jds.S0022-0302 (97)75938-1)

Roche JF, Mackey D \& Diskin MD 2000 Reproductive management of postpartum cows. Animal Reproduction Science 60-61 703-712. (doi:10.1016/S0378-4320(00)00107-X)

Royal M, Mann GE \& Flint AP 2000 Strategies for reversing the trend towards subfertility in dairy cattle. Veterinary Journal 160 53-60. (doi:10.1053/tvjl.1999.0450)

Schmitt EJ, Diaz T, Drost M \& Thatcher WW 1996 Use of a gonadotropinreleasing hormone agonist or human chorionic gonadotropin for timed insemination in cattle. Journal of Animal Science 74 1084-1091.

Scott L \& Whittingham DG 1996 Influence of genetic background and media components on the development of mouse embryos in vitro. Molecular Reproduction and Development 43 336-346. (doi:10.1002/ (SICl)1098-2795(199603)43:3 <336::AID-MRD8>3.0.CO;2-R)

van Soom A, Ysebaert MT \& de Kruif A 1997 Relationship between timing of development, morula morphology, and cell allocation to inner cell mass and trophectoderm in in vitro-produced bovine embryos. Molecular Reproduction and Development 47 47-56. (doi:10.1002/ (SICI)1098-2795(199705)47:1 < 47::AID-MRD7>3.0.CO;2-Q)

Spencer TE, Sandra O \& Wolf E 2008 Genes involved in conceptusendometrial interactions in ruminants: insights from reductionism and thoughts on holistic approaches. Reproduction 135 165-179. (doi:10. 1530/REP-07-0327)

Staples CR, Thatcher WW \& Clark JH 1990 Relationship between ovarian activity and energy status during the early postpartum period of high producing dairy cows. Journal of Dairy Science 73 938-947. (doi:10. 3168/jds.S0022-0302(90)78750-4)

Stokes PJ, Hawkhead JA, Fawthrop RK, Picton HM, Sharma V, Leese HJ \& Houghton FD 2007 Metabolism of human embryos following cryopreservation: implications for the safety and selection of embryos for transfer in clinical IVF. Human Reproduction 22 829-835. (doi:10.1093/humrep/ del447)

Tay JI, Rutherford AJ, Killick SR, Maguiness SD, Patridge RJ \& Leese HJ 1997 Human tubal fluid: production, nutrient composition and response to adrenergic agents. Human Reproduction 12 2451-2456. (doi:10. 1093/humrep.12.11.2451)

Tervit HR, Whittingham DG \& Rowson LE 1972 Successful culture in vitro of sheep and cattle ova. Journal of Reproduction and Fertility $\mathbf{3 0}$ 493-497. (doi:10.1530/jrf.0.0300493)

VanRaden PM \& Sanders AH 2003 Economic merit of crossbred and purebred US dairy cattle. Journal of Dairy Science 86 1036-1044. (doi:10.3168/jds.S0022-0302(03)73687-X)

Wall E, Brotherstone S, Kearney JF, Woolliams JA \& Coffey MP 2005 Impact of nonadditive genetic effects in the estimation of breeding values for fertility and correlated traits. Journal of Dairy Science 88 376-385. (doi:10.3168/jds.S0022-0302(05)72697-7)

Wang X, Schutzkus V, Huang W, Rosa GJ \& Khatib H 2009 Analysis of segregation distortion and association of the bovine FGF2 with fertilization rate and early embryonic survival. Animal Genetics 40 722-728. (doi:10.1111/j.1365-2052.2009.01904.x)

Received 18 June 2010

First decision 9 August 2010

Revised manuscript received 6 January 2011

Accepted 10 February 2011 